поднимаемые в данной статье, найдут отклик и внесут свой вклад в дело успешной подготовки студентов к экзаменам по иностранному языку в вузе.

$$
* * *
$$

1. Newbrook, J. (1973). Activate! Teaching exam skills. Pearson Education Limited.

2. Richards, J.C. (2001). Curriculum development in language teaching. Cambridge University Press.

3. Dornyei, Z. (2001). Motivation strategies in the language classroom. Cambridge University Press.

4. Burgess, S., Head, K. (2005). How to teach for exams. Pearson Education Limited.

5. May,P. (1996). Exam Classes. Oxford University Press.

6. Brook-Hart, G., Jakeman, V. (2015). Complete IELTS. Student's Book.

\title{
Магомедова А.Н. \\ Основание биоэтики и биоэтического воспитания в социально-философском аспекте
}

Дагестанский государственный педагогический университет (Россия, Махачкала)

doi 10.18411/spc-04-03-2018-09

idsp 000001:spc-04-03-2018-09

\section{Аннотация}

В статье на основе анализа гуманитарного базиса философии, социологии, психологии и педагогики рассматривается и обосновывается необходимость биоэтического воспитания.

Ключевые слова: этика, биоэтика, воспитание, биоэтическое воспитание.

В центре внимания многих исследователей находятся вопросы гуманизации и гуманитаризации образования, являющиеся сегодня основными стратегическими направлениями, прежде всего, подготовки педагогических кадров (Е.В. Бондаревская, Н.М. Борытко, М.А. Вейт, В.А. Козырев, Л.Е. Сараскина, В.В. Сериков, В.А. Сластенин, Ю.Г. Фокин, Е.Н. Шиянов и др.), в большей степени влияющих на процессы воспитания личности.

В современном российском образовании, хотя и медленно, но все же идут процессы демократизации, обновляется учебный процесс, а также происходит актуализация общечеловеческих нравственных ценностей: совести, добра, справедливости, милосердия, духовности, человеческого достоинства, т.е. всего того, что составляет гуманитарный базис образования.

Нравственно-этическая основа биоэтики, в наибольшей степени соответствует перечисленным ценностям и, может составить новую концепцию воспитания личности. Основанием для такого заявления служит то, что в философской, социальной, правовой, психологической, педагогической литературе на протяжении ряда лет дебатируются, с одной стороны, вопросы новых подходов к воспитанию личности, а, с другой стороны, этико-правовые, нравственные вопросы, касающиеся детства, сиротства, инвалидности, клонирования, вмешательства в генетический аппарат человека, возникновения «суррогатных матерей», смены пола и, вообще, отношения ко всем проявлениям жизни, но объединить дебаты ученых в русле биоэтического воспитания, пока, не удается. Наши исследования и данная статья - это попытка автора интегрировать содержание научного направления - биоэтику с процессом воспитания личности.

В настоящее время ученые, биоэтики и педагоги вносят весомый вклад в исследование биоэтических вопросов в области экологии, биомедицины, подготовки общественного сознания к восприятию биоэтических идей в системе образования и в средствах массовой информации. Различные аспекты развития биоэтического образования рассматриваются в трудах Б.Г. Юдина, Р.Г. Апресяна, И.В. Силуяновой, 
А.Н. Орлова, М.Я. Яровинского и др. В то же время наблюдается дефицит фундаментальных работ, посвященных теоретическим вопросам биоэтического образования. Еще меньше работ, посвященных биоэтическому воспитанию.

Биоэтические идеи науки и образования появились не так давно. Философские их корни связаны с обсуждением философами категории «ответственности». Ретроспективный анализ научной литературы позволил выявить, что термин «ответственность» (от лат. respondere - отвечать) [13] конституировался впервые в юриспруденции во второй половине XV столетия. Первым, кто раскрыл сущность ответственности, был Ф. Ницше. По его мнению, чтобы соединить «я хочу» и «я делаю», нужна ответственность. Ф. Ницше понимал, что феномен ответственности мог стать значимым лишь в научную эпоху, вместе с появлением «исчислимого» человека. Это означает, что именно этика ответственности наиболее органично коррелирует с ученостью человека [9, С. 440].

Весьма значимым моментом в понимании ответственности следует признать вывод М. Вебера [4, С. 692-698]: «Мы должны уяснить себе, что всякое этически ориентированное действование может подчиняться двум фундаментально различным, непримиримо противоположным максимам: оно может быть ориентировано либо на «этику убеждения», либо на «этику ответственности». Только во втором случае этика становится практической и «надо расплачиваться за (предвидимые) последствия своих действий».

По Х. Ленку [7, С. 222-223], ответственность - это нормативный интерпретационный конструкт. Он различает, по крайней мере, четыре ее типа: ответственность за действия, их последствия, результат; ответственность компетентную и ролевую; ответственность универсально-моральную; ответственность правовую.

Наконец, Г. Йонас [19] выразил то, что, казалось бы, знали и другие: принцип ответственности занимает в этике не рядовое, а ключевое, центральное место. Таким образом, одним из вариантов современной этики выступает биоэтика, которая естественным образом соединена с полем дискурса экологической и прикладной этики. Биоэтика - это область нравственного отношения к окружающему человека миру. Этичный человек не может оставаться равнодушным к страданиям другого, даже если этот другой - животное. Этика отношения к людям и этика отношения к животным биоэтика - имеют одну и ту же психическую основу - способность сопереживания. Поэтому воспитание у детей доброго отношения к живым существам формирует у них такие социально важные качества, как отзывчивость, сопереживание, доброта.

По мнению В. Поттера основателя биоэтики, применение этики не должно ограничиваться только лишь одной сферой человеческих отношений - ее следует распространить на всю биосферу как целое с целью регуляции вмешательства человека в область разнообразных проявлений жизни [11]. Ученый, в одном из своих выступлений сказал о том, что необходимо понимать биоэтику как новое этическое учение, объединяющее смирение, ответственность и компетентность, как науку, которая по своей сути является междисциплинарной, которая объединяет все культуры и расширяет значение слова "гуманность“ (там же).

Взгляд на биоэтику как этику Земли свидетельствует о гуманитаризации человеческого сознания и мировоззрения, появление взгляда на человеческое выживание не с позиции экономики и политики, а с позиции гуманитарнообразовательного подхода к живой природе.

Мы поддерживаем мысль Б.Г. Юдина о том, что в настоящее время биоэтика переживает процесс оформления в качестве «неформального социального института и общественного движения» [3].

И соглашаемся с мнением бывшего генерального директора ЮНЕСКО Ф. Майора, который более 20-ти лет назад высказал мысль о том, что важнейшим 
фактором решения экологических проблем должно стать «глобальное воспитание» [10], которое предусматривает постановку экологических вопросов в центр всех учебных программ, начиная с детских дошкольных учреждений и заканчивая ВУЗами, подготовкой учителей и управленческого аппарата. С нашей точки зрения, ядром такого воспитания должны стать биоэтика и биоэтическое воспитание.

Мы также уверены в том, что путь к экологическому сознанию лежит через формирование особого отношения $[17$, C. 33] к природе и жизни вообще («благоговение перед жизнью» [15]), которое может быть результатом биоэтического воспитания личности.

Необходимо также отметить, что проблемы этики, биоэтики тесно переплетаются с религией и теологическим образованием. И это, по нашему мнению, сильная сторона предлагаемой концепции биоэтического воспитания. Не вдаваясь глубоко в суть проблемы, отметим, что, например, курс «Религия и биоэтика» изучается в православных духовных образовательных учреждениях. Цель данного курса - познакомить студентов отделения теологии с историей влияния религиозных представлений на эволюцию медицинской науки; проявить ее неразрывную связь с религиозной антропологией и этикой; раскрыть современные проблемы прикладной этики и способы их решения в аспекте православной духовной традиции.

Введение курса было связано с тем, что в 1994 г. Папская академия в защиту жизни (см. ст. Академии Папские) приняла «Хартию работников здравоохранения», согласно которой «все работники здравоохранения должны быть подготовлены в вопросах морали и биоэтики» [2, С. 17]. Создание «христианской биоэтики» как целостной богословской системы объявляется задачей будущего. В настоящее время биоэтика сводится к философскому анализу, оценке и классификации случаев применения биомедицинских технологий, их последствий, судеб пациентов. Подчеркивается, что решение любого частного вопроса биомедицинской этики должно осуществляться исключительно в соответствии с основополагающими христианскоантропологическими принципами: утверждением достоинства и богоподобия человека, пониманием тела человека как Божия храма, усматриванием значимого смысла страданий и смерти [20, S. 8.].

В 1998 г. Святейший Патриарх Московский и всея Руси Алексий II благословил создание при Московском Патриархате Церковно-общественного Совета по биомедицинской этике. К основным задачам деятельности Совета относятся: 1) морально-нравственная и правовая экспертиза экспериментальной и научно-практической деятельности в области биомедицины; 2) изучение состояния биомедицинских исследований в России; 3) информирование и консультирование широких слоев общественности по всему кругу этических проблем современной медицины [12, С. 218-221].

Для нашего исследования важно, что согласно плану действий, предложенному Всемирной конференцией по науке, состоявшейся в Будапеште в 1999 г., вопросы этики и ответственности науки должны быть интегральной частью образования ... и необходимо стимулировать со стороны ученых уважение и приверженность основным этическим принципам и ответственности науки [21, Р.295-306].

$$
* * *
$$

1. Баньковская С.П. Инвайронментальная социология. - Рига, 1991. - С. 45.

2. Ватикан. - М., 1996. - С. 17.

3. Введение в биоэтику / Под ред. Б.Г. Юдина - М.: Прогресс-Традиция, 1998. - 384 с.

4. Вебер М. Избранные произведения. - М: Прогресс, 1990. - С. 692-698.

5. Глазачев С.Н. Экологическая культура учителя: Исследования и разработки экогуманитарной парадигмы. - М.: Современный писатель, - 1998. - 432 с.

6. Золотухина-Аболина Е.В. Современная этика: Учебное пособие для студентов вузов. - 3-е изд., перераб. и доп. - М.: ИКЦ «МарТ», 2005. - С. 402-411.

7. Ленк Х. Размышления о современной технике. - М.: Аспект Пресс, 1996. - С. 222-223. 
8. Лихачев Д.С. Экология - проблема нравственная // Наше наследие. - М., 1991. - № 1. - С. 3-7.

9. Ницше Ф. Сочинения: В 2-х т. Т.2.- М.: Мысль, 1990. - С. 440.

10. Обращение к Глобальному форуму по защите окружающей среды и развитию. - Москва, 1990.

11. Поттер В.Р. Биоэтика: мост в будущее. - Киев: Изд. Вадим Карпенко, 2002. - 216 с.

12. Православная энциклопедия. / Под. ред. Патриарха Московского и всея Руси Алексия II. T.V, - M., 2002. - C. 218-221.

13. Словарь иностранных слов. - М.: Мир, 2006.

14. Харченко Л.Н. и др. Современное биологическое образование. Теоретический и технологический аспекты. - М.:Илекса - Ставрополь: Сервисшкола, 2005. - 320 с.

15. Швейцер А. Культура и этика / пер. с нем. - М.: Прогресс, 1973.- 344 с.

16. Шелер М. Формы знания и образование // Шелер М. Избранные произведения / пер. с нем. А.В. Денежкина, А.Н. Малинкина, А.Ф. Филиппова; под ред. А.В. Денежкина. М.: Гнозис, 1994. - 490 с.

17. Ясвин В.А. Психология отношения к природе. - М.: «Смысл», 2000. - С. 219-223.

18. Bioethics Core Curriculum Proposal: Version 1.0 (Draft, 1 May 2007), http://unesdoc.unesco.org/ulis/cgibin/ulis.pl?catno $=152487 \& \mathrm{gp}=0 \&$ mode $=\mathrm{e} \&$ lin

19. Jonas H. Das Prinzip Verantwortung. Versuch einer Ethik fuer die technologische Zivilisation. - Fr. a. M., 1979.

20. Low R. Anthropologische Grundlagen einer christianichen Bioethik // Bioethik. - 1996. - S. 8.

21. Thomasma D. Bioethics and International Human Rights // J. of Law, Medicine \& Ethics. - 1997. -№25. P.295-306.

\author{
Маль Г.С. ${ }^{1}$, Дородных И.А. ${ }^{2}$ \\ Применение практико- ориентированного обучения \\ для подготовки медицинских кадров \\ ${ }^{1}$ Курский государственный медииинский университет» Минздрава России \\ ${ }^{2}$ Курский базовый медииинский колледж
} (Россия, Курск)

doi 10.18411/spc-04-03-2018-10

idsp 000001:spc-04-03-2018-10

Сегодня невозможно освоить медицинскую специальность раз и навсегда. В век быстро развивающихся медицинских технологий сокращается жизненный цикл знаний и умений медицинского персонала и поэтому все более возрастает потребность в программах повышения квалификации, построенных на основе практикоориентированного обучения[1]

По определению ЮНЕСКО под практико-ориентированным обучением, основанном на компетенциях, понимается «обучение, основанное на определении, освоении и демонстрации знаний, умений, типов поведения и отношений, необходимых для конкретной профессиональной (трудовой) деятельности» [2].

Практико-ориентированное обучение отличает постоянная нацеленность на конечный результат. Невозможно сегодня на всю жизнь сформировать набор компетенций среднего медицинского персонала. Важнее научить специалиста формировать и развивать компетенции самостоятельно. Поэтому наряду с традиционными экзаменами, направленными на проверку памяти, знаний и умений, должны быть введены критерии, которые станут индикаторами оценки целостных компетенций, такие как:

- демонстрация действий в ситуации, максимально приближенной к практической деятельности;

- результаты индивидуальной или групповой проектной деятельности.

Решение проблемы практико-ориентированного обучения медицинского персонала начинается с вопроса о постановке ее цели. Обратимся к модели педагогической деятельности, ядром которой является понятие о структуре этой деятельности. Можно выделить четыре основных компонента педагогической деятельности, включенных в практико-ориентированные занятия: конструктивного, 